\title{
Prevalence of chronic wet cough and protracted bacterial bronchitis in Aboriginal children
}

\author{
Pamela Laird (1) 1,2,3, James Totterdell (10 ${ }^{4}$, Roz Walker ${ }^{5}$, Anne B. Chang ${ }^{6,7}$ and \\ André Schultz ${ }^{1,3,8}$
}

Affiliations: ${ }^{1}$ Children's Lung Health Division, Telethon Kids Institute, Perth, Australia. ${ }^{2}$ Dept of Physiotherapy, Perth Children's Hospital, Perth, Australia. ${ }^{3}$ School of Medicine, Dept of Paediatrics, University of Western Australia, Perth, Australia. ${ }^{4}$ Wesfarmers Centre of Vaccines and Infectious Diseases, Telethon Kids Institute, Perth, Australia. ${ }^{5}$ Poche Centre for Indigenous Health, School of Indigenous Studies, University of Western Australia, Perth, Australia. ${ }^{6}$ Child Health Division, Menzies School of Health Research, Charles Darwin University, Darwin, Australia. ${ }^{7}$ Dept of Respiratory and Sleep Medicine, Queensland Children's Hospital, Queensland University of Technology, Brisbane, Australia. ${ }^{8}$ Dept of Respiratory and Sleep Medicine, Perth Children's Hospital, Perth, Australia.

Correspondence: Pamela Laird, Dept of Physiotherapy, Perth Children's Hospital, 15 Hospital Ave, Nedlands, WA 6009, Australia. E-mail: Pamela.Lairdahealth.wa.gov.au

\section{ABSTRACT}

Background: Chronic wet cough, the most common symptom of a disease spectrum that encompasses protracted bacterial bronchitis $(\mathrm{PBB})$ and bronchiectasis, is common among Aboriginal children. In the absence of any community prevalence data, and with the high burden of respiratory disease and the European Respiratory Society task force's recommendation to identify disease burden, we determined the prevalence of chronic wet cough and PBB in young Aboriginal children in four remote communities in north Western Australia.

Methods: A whole-population, prospective study was conducted. Aboriginal children aged $\leqslant 7$ years were clinically assessed for chronic wet cough by paediatric respiratory clinicians between July 2018 and May 2019. Where children had a wet cough but parents reported a short or uncertain cough duration, children were followed up 1 month later. A medical record audit 6 weeks to 3 months later was used to determine those children with chronic wet cough who had PBB (based on response to antibiotics).

Results: Of the 203 children, 191 (94\%; median age 3.5 years, range 0-7 years) were enrolled. At the initial visit, chronic wet cough was present in 21 (11\%), absent in $143(75 \%)$ and unknown in 27 (14\%). By follow-up, the total prevalence of chronic wet cough was 13\% (95\% CI 8-19\%) and 10\% (95\% CI 7-17\%) for PBB. Chronic wet cough was more common in the two communities with unsealed roads (19\%) compared to the two with sealed roads (7\%).

Conclusion: Given the relatively high prevalence, strategies to address reasons for and treatment of chronic wet cough and PBB in young Aboriginal children in remote north Western Australia are required.

@ERSpublications

Prevalence of chronic wet cough and protracted bacterial bronchitis in Aboriginal children in remote, north Western Australia is high. There is a need to implement strategies to detect and manage these entities and measure prevalence in other settings. http://bit.ly/33QLzDA

Cite this article as: Laird $\mathrm{P}$, Totterdell J, Walker $\mathrm{R}$, et al. Prevalence of chronic wet cough and protracted bacterial bronchitis in Aboriginal children. ERJ Open Res 2019; 5: 00248-2019 [https:// doi.org/10.1183/23120541.00248-2019].

This article has been republished with a correction to one of the authors' affiliations.

This article has supplementary material available from openres.ersjournals.com

Received: 13 Sept 2019 | Accepted after revision: 17 Oct 2019 | First published: 8 Dec 2019

Copyright $\odot$ ERS 2019. This article is open access and distributed under the terms of the Creative Commons Attribution Non-Commercial Licence 4.0. 


\section{Introduction}

Chronic wet cough is the most common symptom of a chronic suppurative airway disease spectrum that encompasses protracted bacterial bronchitis (PBB) and bronchiectasis [1]. These diseases are characterised by neutrophilic airway inflammation, endobronchial bacterial infection and impaired mucociliary clearance [2]. If left untreated, $\mathrm{PBB}$ can result in progressive and permanent damage, i.e. bronchiectasis [3] Bronchiectasis, particularly prevalent and severe among Aboriginal Australians, impairs general health, and reduces quality of life and life expectancy [4-7]. Australian Aboriginal children suffer a considerable and disproportionate burden of respiratory disease [8] with one Australian study reporting bronchiectasis prevalence of $1.5 \%$ [9]. Similar rates of bronchiectasis have been reported in other Indigenous populations living in high-income countries [10].

Disease progression in bronchiectasis can be halted in most children and, in some cases, reversed when diagnosed and treated early $[2,11]$. Thus, the early recognition and prompt treatment of chronic wet cough in children is important for the prevention of bronchiectasis and for limiting progression of established disease $[2,11]$.

There are few data on the prevalence of chronic wet cough and the burden of PBB in any setting. Most studies have relied on children presenting to hospitals or specialist clinics rather than community-acquired data [12-15]. Indeed, determining the prevalence of PBB in children is one of the clinical research gaps identified in the European Respiratory Society PBB task force document [16].

In the absence of such data among Aboriginal children and with the high reported prevalence of bronchiectasis [9], we aimed to determine the prevalence of chronic wet cough and PBB in young Aboriginal children living in four remote communities in the Kimberley region of Western Australia. Our secondary aim was to explore possible factors that may influence the prevalence of chronic wet cough and PBB.

\section{Materials and methods}

\section{Participants and study design}

We undertook a whole-population study of Aboriginal children aged $\leqslant 7$ years across two time-points, 1 month apart. Figure 1 outlines the recruitment and data collection process.

\section{Setting}

The study was conducted in four coastal remote Aboriginal communities (table 1) in the Kimberley region, north Western Australia, between July 2018 and May 2019. The region has high rates of respiratory

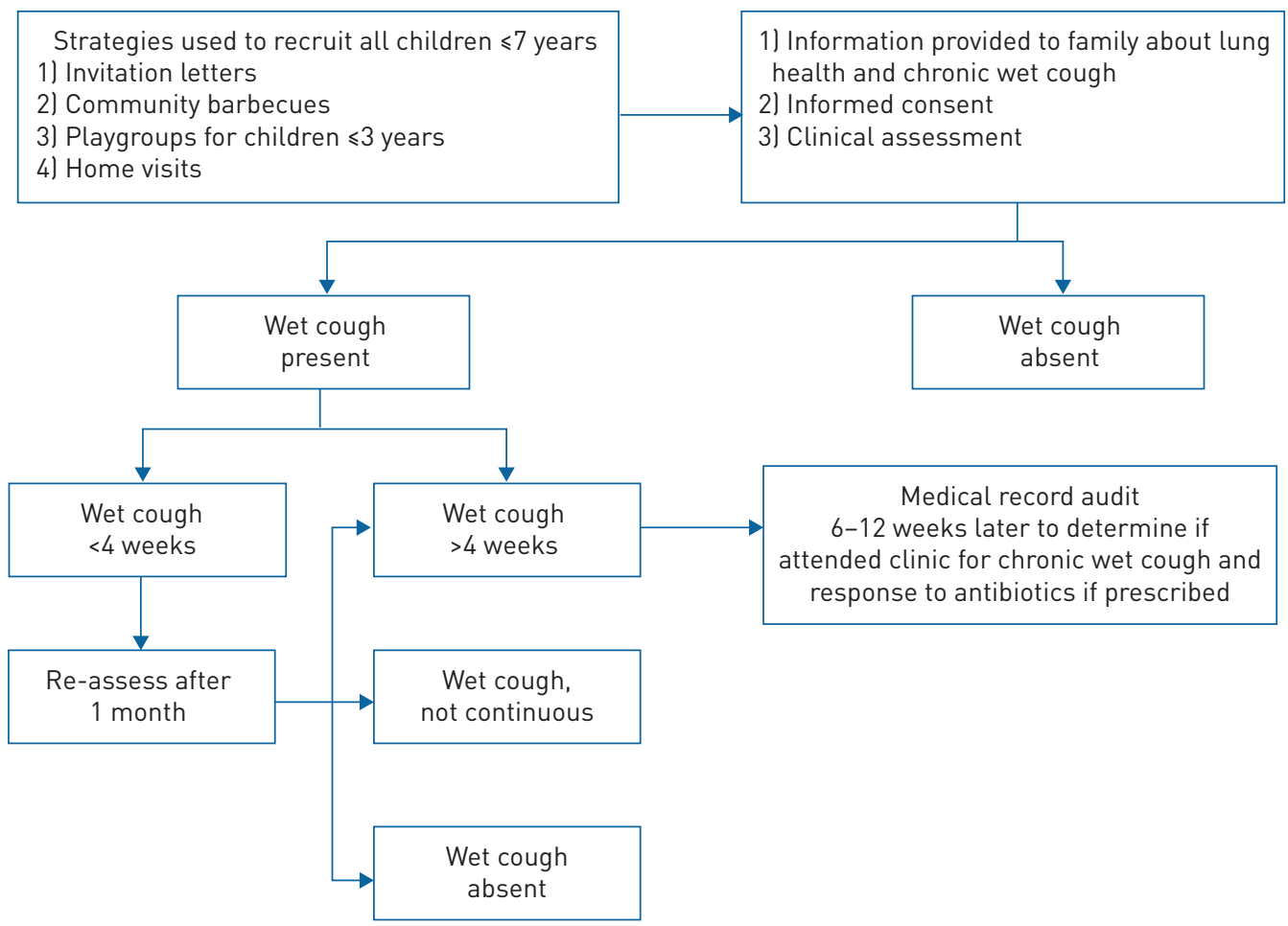

FIGURE 1 Process of recruitment and data collection. 


\begin{tabular}{|c|c|c|c|c|}
\hline Community & $\begin{array}{l}\text { Total population size } \\
\text { (including adults) }\end{array}$ & $\begin{array}{l}\text { Season when children } \\
\text { were assessed }\end{array}$ & $\begin{array}{l}\text { Road surface } \\
\text { in community }\end{array}$ & $\begin{array}{l}\text { Type of health } \\
\text { service }\end{array}$ \\
\hline 1 & 750 & Dry ( Jul-Aug 2018) & Unsealed & Aboriginal controlled \\
\hline 2 & 285 & Wet (Mar-Apr 2019) & Sealed & Aboriginal controlled \\
\hline 3 & 240 & Wet (Mar-Apr 2019) & Unsealed & State government \\
\hline 4 & 330 & Wet (Mar-Apr 2019) & Sealed & State government \\
\hline
\end{tabular}

infections [8] and disease [17]. The Kimberley region is about three times the size of England (UK), with a tropical monsoon climate. Each community is classified as "very remote" based on Australia's classification [18] and located within a 220-km radius of Broome, the region's largest town and closest hospital. Western Australia's only paediatric tertiary hospital is located $2200 \mathrm{~km}$ south, in Perth.

Ethical approval was granted by the Western Australian Aboriginal Health Ethics Committee (HREC 834) and the Western Australian Country Health Ethics Committee (RGS 1374). All parents/carers of child participants provided written, informed consent.

\section{Sampling strategy}

The number of children residing in each community was ascertained through the local community's electronic medical record system, wherein all children are registered. Local Aboriginal health workers and clinic administration staff determined which child was present in each community during the week of recruitment. The small size of the communities and strong cultural networks allows local Aboriginal clinic staff to know all members of the community. The total number of children in community at recruitment was recorded as the total population number of children.

\section{Recruitment}

Letters were sent to families 1 week prior to recruitment to inform families about the study and invite participation of their children. We recruited over a 1-week period in each community at local community barbecues, at playgroups for children $\leqslant 3$ years of age and through home visits.

As part of the informed consent process, parents were provided with education about lung health, PBB and the importance of chronic wet cough, using a locally adapted, culturally informed education resource (flip chart). Information flip charts have been shown to improve knowledge of lung health for Aboriginal families [19], and our flip chart was specifically developed to enable Kimberley Aboriginal families to recognise and seek help for chronic wet cough [20].

\section{Data collection}

Data were collected using a standardised format as each child was assessed by two paediatric respiratory clinician-researchers (physician and/or physiotherapist) and an Aboriginal coresearcher.

\section{Medical history and clinical assessment}

Clinicians asked parents/carers about the child's exposure to tobacco smoke and whether their child had a current cough. If current cough was present, parents were asked about the cough quality (wet or dry) and the number of consecutive days of cough. The former has previously been validated, i.e. assessment of cough quality agreed with bronchoscopic findings [21] (i.e. wet cough is a marker of the presence of lower airway secretions). Children were recorded as having chronic wet cough if the child's current cough was determined to be wet by a clinician-researcher and parents reported that their child had daily wet cough for $\geqslant 4$ weeks.

The same clinicians assessed each child's cough quality across all communities. Initially, the child was asked to cough and the cough characteristics (i.e. wet or dry) recorded. If the child could not cough on command, the physiotherapist performed noninvasive techniques to elicit a cough, which included blowing whistles, bubbles, positive expiratory pressure therapy and the "huff" manoeuvre. The huff is a forced expiratory manoeuvre, usually initiated from mid-to-low lung volumes via an open glottis [22]. The child was asked to huff at various inspiratory and expiratory breath volumes, before the child either coughed spontaneously or was asked to cough. Respiratory findings including respiratory rate, chest wall shape and auscultation were documented. The respiratory physician assessed children for specific alternative causes of respiratory diseases such as aspiration and asthma. 
A second assessment was performed 1 month later on children if the parent/carer: 1) reported wet cough but of $<4$ weeks or uncertain duration; or 2) initially reported a dry cough but the clinician assessed the child's cough as wet. In the latter children, the researchers verified that families understood how a wet cough sounds. In both scenarios, parents were asked to monitor for presence or absence of daily wet cough over the following month.

The second assessment 1 month after the initial study visit was conducted to allow parents to carefully observe their child's cough because prior to receiving knowledge about lung health and chronic wet cough, chronic wet cough is often unnoticed or normalised [20]. Similar to the first study visit, children were deemed to have chronic wet cough if parents reported that their child had daily wet cough for $\geqslant 4$ weeks and the child's current cough was determined to be wet by a clinician-researcher.

Children with chronic wet cough at any point in the study were referred to the local medical clinic to be treated by local doctors. Prior to this study, we also provided specific training to local clinicians on the management of chronic wet cough according to best practice guidelines [23] using strategies to address enablers and barriers for health practitioners [24].

\section{Concurrent hospitalisation rate in the region}

To investigate the potential effect of seasonal variation on rates of chronic wet cough, hospitalisation rates for lower respiratory tract infections in children at the only local regional hospital was compared to chronic wet cough rates for corresponding months of data collection. Hospitalisation data were obtained through coding from the hospital's electronic record system.

\section{Protocol definitions}

Chronic wet cough

Chronic wet cough was defined as daily wet cough present for $\geqslant 4$ weeks, as reported by parent/carer and confirmed by clinician assessment of cough.

\section{Protracted bacterial bronchitis}

PBB was defined as chronic wet cough that responded to appropriate antibiotic therapy (amoxycillin/ clavulanate or azithromycin) for 2-4 weeks as determined by doctors at the local clinic. Antibiotic prescription was repeated for a further 2 weeks if wet cough persistent at the 2-week review. Resolution of cough was determined by the treating doctor and data was collected from the medical records 3 months after the 1-month follow-up study visit.

\section{Analysis}

Data were recorded and analysed in SPSS (version 25; IBM, Armonk NY, USA). From the assessments, we calculated prevalence estimates and 95\% confidence intervals of chronic wet cough and PBB overall and specific to each community for the 1 -month period based on this flow of children. We undertook secondary analyses to investigate possible reasons why prevalence may differ between the communities by consideration of season of measurement, road status and smoking exposure using logistic regression summarised by odds ratios, $95 \%$ profile confidence intervals and Chi-squared tests.

We tabulated hospitalisation counts of children during the study period as a pragmatic way to evaluate the relationship between seasonal respiratory infections and chronic wet cough. Lastly, we used Cohen's $\kappa$ to determine the agreement between parent report and clinician assessment at initial and subsequent assessments.

\section{Results}

A total of 203 children aged $\leqslant 7$ years were present in the four communities during the recruitment period. Of these, $94 \%(n=191)$ were recruited (median age 3.5 years, range $0-7$ years) and $51 \%(n=98)$ were male. The 12 children who were not recruited could not be located during the recruitment period, despite the best efforts of the research team. All parents agreed to participate. 78 children had a wet cough (for $<4$ weeks) at recruitment and required follow-up a month later. 27 of these (30\%) were lost to follow-up a month later (left community and/or could not be located). Combined community results for all participants' cough outcomes at each of the two assessment time points are illustrated in figure 2.

\section{Chronic wet cough}

Of the 191 children assessed, chronic wet cough was present in 21 (11\%), absent in 143 (75\%) and unknown in 27 (14\%). This suggested a plausible sample prevalence range from 11\% (21 out of 191) to 25\% (48 out of 191) (if all 27 children lost to follow-up had chronic wet cough) over the 1-month period of assessment and a prevalence estimate of 13\% (95\% CI 8-19\%) across all communities assessed. 


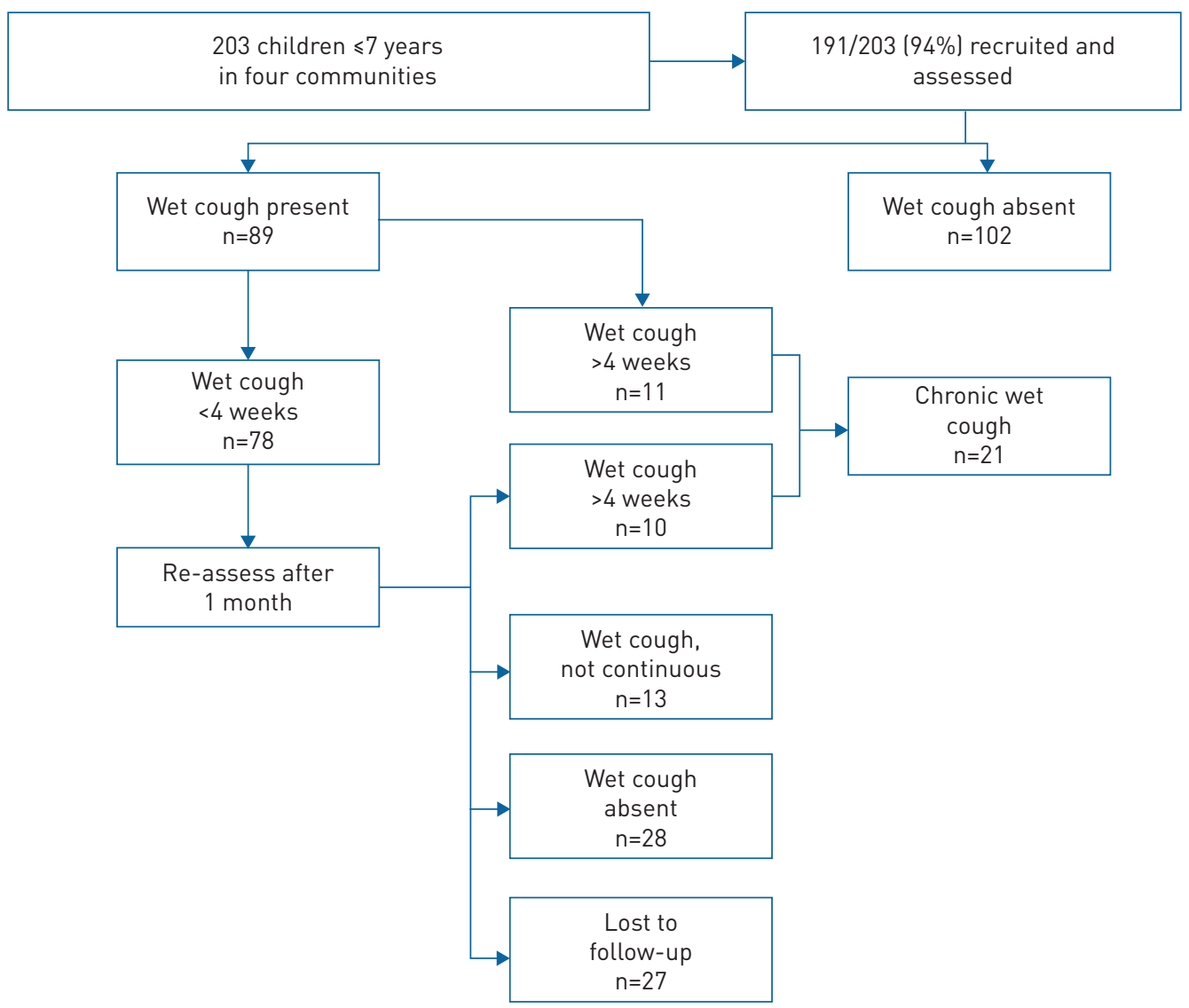

FIGURE 2 Results of cough status at recruitment and 1-month follow-up in Aboriginal children in four remote communities.

The median age of the 21 children $(10$ male) with confirmed chronic wet cough was 2.4 years (range 0.3-74 years) and the median duration of cough was 35 days (range 28-700 days). In most children with chronic wet cough, clinical examinations were normal, i.e. they had a normal chest wall $(100 \%, 21$ out of $21)$, normal respiratory rate $(95 \%, 20$ out of 21$)$ and a clear chest on auscultation $(62 \%, 13$ out of 21$)$. None had clinical signs suggesting chronic disease apart from crepitations on auscultation of the chest.

Detailed information on immunisation status, previous respiratory hospitalisations, gestation at birth, tobacco smoke exposure and auscultation findings are detailed in supplementary table S1.

\section{Protracted bacterial bronchitis}

$16(76 \%)$ out of 21 children with chronic wet cough presented to clinic for management by local doctors. All 16 children were given antibiotics for 2-4 weeks (depending on response) and all had complete resolution of cough symptoms. Of the remaining five children, the cough spontaneously resolved in two (based on parental report) and three were lost to follow-up.

Thus, of the 191 children assessed at the commencement of the study, PBB was confirmed in 16 (8\%), absent in $145(76 \%)$ and unknown in 30 (16\%). This suggested a plausible sample prevalence range of $8 \%$ ( 16 out of 191) to $24 \%$ (46 out of 191) (if all 30 children lost to follow-up had PBB) and a PBB prevalence estimate of $10 \%$ (95\% CI 6-16\%). The median age of the 16 children with PBB was 2.3 years (range 0.3-7 years; six male) and median duration of cough was 33 days (range 28-90 days) (figure 3).

\section{Community differences}

Detailed results of the rates of chronic wet cough and $\mathrm{PBB}$ for all participants, per community, are outlined in table 2. Prevalence of chronic wet cough in the communities assessed ranged from 5\% (two out of 40 ) to $22 \%$ (11 out of 50) (table 2).

The communities with unsealed roads had higher prevalence of chronic wet cough and PBB than the two communities with sealed roads (i.e. a road surface that has been permanently sealed by the use of a 


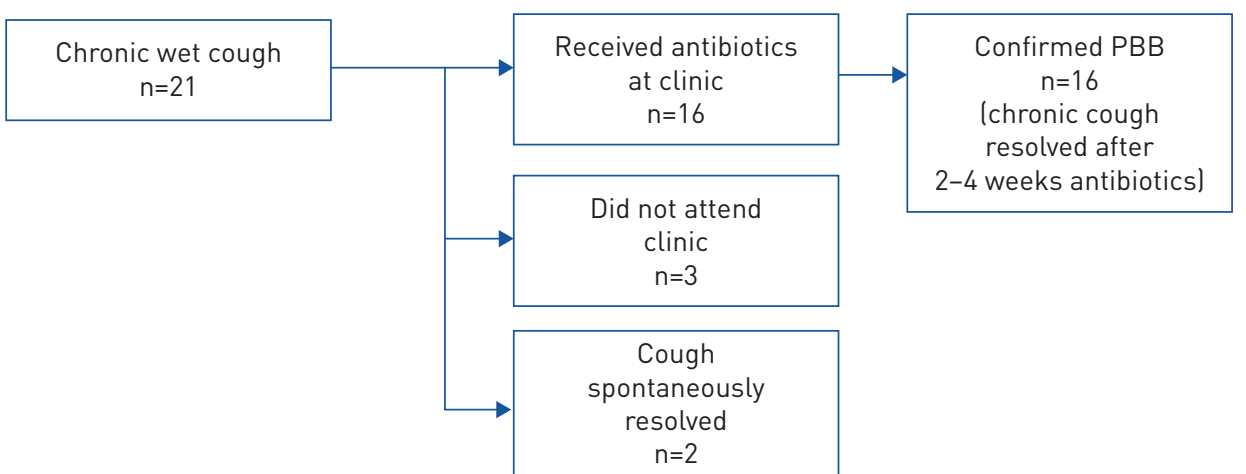

FIGURE 3 Outcomes of children with chronic wet cough. PBB: protracted bacterial bronchitis.

pavement treatment, often of composite construction). Prevalence of chronic wet cough in communities with unsealed roads was 19\% (15 out of 80 ) compared to $7 \%$ (six out of 84 ) with sealed roads (OR 3.0, 95\% CI 1.2-8.9; $\mathrm{p}=0.02$ ). Prevalence of PBB in communities with unsealed roads was $15 \%$ (12 out of 79) compared to $5 \%$ (four out of 82 ) with sealed roads (OR 3.5, 95\% CI 1.2-13.1; $\mathrm{p}=0.02$ ).

Community 1 had measurements taken during the dry season and had the highest estimated prevalence of chronic wet cough amongst all communities. The observed prevalence during the wet season was $8 \%(10$ out of 118 ) compared to $22 \%$ (11 out of 50 ) during dry season.

\section{Concurrent hospitalisation rate in the region}

Hospital admissions for respiratory illness for children in the region during the time of the study was similar across all study sites. There were 12 admissions in the preceding 2 months and six admissions for the month of the study when the study was conducted in community 1 . There were eight admissions in the preceding 2 months and six admissions in the month of the study when the study was conducted in the remaining communities.

\section{Secondary tobacco smoke exposure}

The prevalence of children exposed to tobacco smoke was $74 \%$ (128 out of 174) across all communities. While children with chronic wet cough had high exposure to tobacco smoke $(81 \%, 17$ out of 21$)$, the odds of having chronic wet cough was similar between children exposed and unexposed to smoking (OR 1.6, 95\% CI 0.6-5.2).

\section{Cough quality: agreement between clinician assessment and parent report}

Clinician assessment of cough and comparison with parental report of cough quality is presented in table 3. At recruitment, there was substantial agreement ( $\kappa=0.64,95 \%$ CI $0.5-0.8$ ) and at 1-month follow up, almost perfect agreement $(\kappa=0.92,95 \%$ CI $0.8-1.0)$. Cough could not be elicited in 48 out of 191 children at recruitment and in two out of 51 children a month later.

\section{Discussion}

In this first community-based study, the prevalence of chronic wet cough and PBB in young Aboriginal children was $13 \%$ and $10 \%$, respectively. Prevalence of chronic wet cough and PBB were higher in communities where roads were unsealed (19\% and $15 \%$, respectively) than in communities with sealed

\section{TABLE 2 Detailed results of all children aged $\leqslant 7$ years by community}

\begin{tabular}{|c|c|c|c|c|c|c|c|c|c|c|c|}
\hline \multirow[t]{2}{*}{ Community } & \multirow[t]{2}{*}{$\begin{array}{l}\text { Male/ } \\
\text { female }\end{array}$} & \multirow{2}{*}{$\begin{array}{l}\text { Age years } \\
\text { median } \\
\text { (range) }\end{array}$} & \multirow{2}{*}{$\begin{array}{l}\text { Clinician-assessed } \\
\text { wet cough at } \\
\text { recruitment }\end{array}$} & \multicolumn{4}{|c|}{$\begin{array}{l}\text { Chronic wet cough at recruitment and } \\
\text { follow-up }\end{array}$} & \multicolumn{4}{|c|}{ Protracted bacterial bronchitis } \\
\hline & & & & Present & Absent & $\begin{array}{l}\text { Lost to } \\
\text { follow-up }\end{array}$ & $\begin{array}{l}\text { Prevalence } \\
\text { (95\% CI] }\end{array}$ & Present & Absent & $\begin{array}{l}\text { Lost to } \\
\text { follow-up }\end{array}$ & $\begin{array}{l}\text { Prevalence } \\
\text { (95\% CI] }\end{array}$ \\
\hline $1(n=65)$ & $31 / 34$ & $3.3(0.0-7.0)$ & $44(68 \%)$ & $11(17 \%)$ & $39(60 \%)$ & $15(23 \%)$ & $22 \%(12-36 \%)$ & $8(12 \%)$ & $41(63 \%)$ & $16(25 \%)$ & $16 \%(8-30 \%)$ \\
\hline $2(n=42)$ & $22 / 20$ & $3.1(0.1-6.8)$ & $9(21 \%)$ & $2(5 \%)$ & $38(90 \%)$ & $2(5 \%)$ & $5 \%(1-18 \%)$ & $2(5 \%)$ & $38(90 \%)$ & $2(5 \%)$ & $5 \%(1-18 \%)$ \\
\hline $3(n=35)$ & $15 / 20$ & $3.3(0.2-6.8)$ & $16(46 \%)$ & $4(11 \%)$ & $26(74 \%)$ & $5(14 \%)$ & $13 \%(4-32 \%)$ & $4(11 \%)$ & $26(74 \%)$ & $5(14 \%)$ & $13 \%(4-32 \%)$ \\
\hline $4(n=49)$ & $30 / 19$ & $3.7(0.0-7.0)$ & $13(26 \%)$ & $4(8 \%)$ & $40(82 \%)$ & $5(10 \%)$ & $9 \%(3-22 \%)$ & $32(4 \%)$ & $40(82 \%)$ & $7(14 \%)$ & $5 \%(9-17 \%)$ \\
\hline Total $(n=191)$ & $98 / 93$ & $3.5(0.0-7.0)$ & $82(43 \%)$ & $21(11 \%)$ & 143 (75\%) & 27 (14\%) & $13 \%(8-19 \%)$ & $16(8 \%)$ & $145(76 \%)$ & 30 (16\%) & $10 \%(6-16 \%)$ \\
\hline
\end{tabular}




\begin{tabular}{|c|c|c|c|c|c|c|}
\hline \multirow[t]{2}{*}{ Parent report of cough type } & \multicolumn{3}{|c|}{$\begin{array}{l}\text { Clinician assessment of } \\
\text { cough at recruitment }\end{array}$} & \multicolumn{3}{|c|}{$\begin{array}{l}\text { Clinician assessment of } \\
\text { cough at 1-month follow-up }\end{array}$} \\
\hline & Wet & Dry & Total & Wet & Dry & Total \\
\hline Wet & 59 & 3 & 62 & 26 & 2 & 28 \\
\hline Dry & 23 & 58 & 81 & 0 & 21 & 21 \\
\hline Total & 82 & 61 & 143 & 26 & 23 & 49 \\
\hline
\end{tabular}

roads ( $7 \%$ and $5 \%$, respectively). Tobacco smoke exposure was high in all communities but no different between children with and without chronic wet cough.

To the best of our knowledge, there are no whole-community prevalence data on chronic wet cough or PBB. One Australian study prospectively followed children who presented to a paediatric emergency department with acute respiratory infection. PBB was subsequently diagnosed in 55 (10\%) out of 558 children [13]. Other studies, conducted in specialist respiratory clinics in Australia [14, 15] and Turkey $[12,25]$, reported prevalence of $\mathrm{PBB}$ between $11 \%$ and $41 \%$. While these studies demonstrate high prevalence of $\mathrm{PBB}$ in children presenting for medical care, our study findings provide important insight into the burden of disease at a whole-community level in a setting where respiratory diseases are common.

PBB is conceptually understood as a potential pre-bronchiectatic state in some children [1]. Bronchiectasis rates in indigenous children is high and yet it remains one of the most neglected diseases in respiratory health [26]. Given that Aboriginal children have higher rates and risk of bronchiectasis [10], there is a heightened need for culturally informed management of $\mathrm{PBB}$ to prevent development of bronchiectasis and to reduce associated morbidity. Our data suggest that the prevalence of PBB could be considerably greater than originally suspected, and our findings reinforce international calls for a better understanding of prevalence, disease burden and natural history of $\mathrm{PBB}$ in communities and its relationship to the development of bronchiectasis [16]. This is particularly important in indigenous settings as: 1) adults with bronchiectasis who have been symptomatic since childhood (compared to adult-onset symptoms) have significantly poorer clinical outcomes (lower lung function, worse radiology scores and more exacerbations) [27]; and 2) Indigenous Australian adults with bronchiectasis die 22 years earlier than non-Indigenous Australian adults with bronchiectasis [4, 7].

The prevalence of chronic wet cough and PBB varied among the communities, ranging from 5\% to $22 \%$ for chronic wet cough and $5 \%$ to $16 \%$ for $\mathrm{PBB}$. Chronic wet cough and $\mathrm{PBB}$ were more prevalent in communities with unsealed roads. Chronic wet cough was also most prevalent in the community where measurements were obtained during the dry season compared to those where measurements were taken in the wet season. We can only speculate on the reasons for this. Environmental dust exposure may, at least partly, contribute to the differences in rates of chronic wet cough and PBB observed within communities. Airborne geogenic dusts, high in iron ore, are highly prevalent in remote areas and higher in the dry season in northern Western Australia [28]. Geogenic dust particulate matter, including iron ore particles, from remote Western Australia towns can induce a potent acute inflammatory response in the lungs [29]. Furthermore, bacterial pathogens, including Haemophilus influenzae, Streptococcus pneumoniae and Moraxella catarrhalis, are prevalent in the upper airway in Aboriginal children [30], and the survival and virulence of these organisms are influenced by the availability of iron [31]. These common upper airway bacterial pathogens are also the most prevalent pathogens found in the lower airways of children with $\mathrm{PBB}$ [32]. Hence, there may be a relationship between environmental, iron-rich particulate dust exposure and the development of chronic bacterial infections in Aboriginal children, including chronic wet cough and PBB. However, at this point, the association is conjectural.

Our definition of PBB is now the current standard as determined in the USA [33, 34] and by the European Respiratory Society [16]. Some may argue that environmental pollutants could cause the cough rather than infection. However, as outlined above, environmental exposure in the context of the study would predispose to infection, and all 16 children who were given antibiotics had complete resolution of cough and had been coughing for up to 3 months. The prompt resolution of chronic cough after the administration of antibiotics suggests that the chronic wet cough was caused, at least in part, by infection.

Tobacco smoke exposure in the four communities was high (74\%), similar to Aboriginal remote community rates reported by the Australian Bureau of Statistics (73\%) [35]. In our study, there was not 
strong evidence of a relationship between tobacco smoke exposure and chronic wet cough or PBB. However, tobacco exposure is a well-documented risk factor for development of chronic respiratory diseases [36], and a true relationship may be obscured by confounding factors and the high rates of exposure of the majority of children in the communities.

A limitation of our study design was the reliance on parental reporting of cough symptoms in the month between clinician assessments. It is possible that symptoms were under-reported if parents were not aware of daily cough or if cough was normalised [20]. However, there was excellent agreement between parent and clinician report of wet/dry cough. This strong agreement highlights how accurate medical history can be obtained in an Aboriginal setting using culturally informed methods [20] and validates the accuracy of parental reporting of daily ongoing wet cough symptoms in those children with chronic wet cough/PBB. CHANG et al. [21] also reported good agreement between clinician and parent report of cough quality, which correlated with bronchoscopic findings.

Another limitation of our study was the absence of objective lung function data. However, spirometry and forced oscillatory test indices are normal in children with PBB [37], and most children with mild bronchiectasis [2].

In conclusion, the prevalence of chronic wet cough and PBB in young Aboriginal children in remote, north Western Australia is high. There is a need to implement strategies to facilitate detection and management of chronic wet cough and $\mathrm{PBB}$, as well as measure the prevalence in other settings.

Acknowledgements: The authors thank the Kimberley Aboriginal Medical Service for their support and collaboration in all aspects of the planning and operation of the study.

Conflict of interest: P. Laird reports grants (NHMRC PhD Scholarship, Hot North and Stan and Jean Perron Top-up Scholarships) from the National Health and Medical Research Council, Australia, Menzies school of Health Research and Stan and Jean Perron Foundation during the conduct of the study. J. Totterdell has nothing to disclose. R. Walker has nothing to disclose. A.B. Chang reports grants (project, Centre for Research Excellence and practitioner fellowship) from the National Health and Medical Research Council, Australia during the conduct of the study; and other potential conflict from being an author in UpToDate and USA Chest Chronic Cough Guidelines outside the submitted work. A. Schultz reports a grant (APP1131932) and a TRIP Fellowship (APP1168022) from National Health and Medical Research Council, Australia, during the conduct of the study.

Support statement: The project was funded by a Hot North Pilot grant from the Menzies School of Health Research. P. Laird was supported by a National Health and Medical Research Council (NHMRC) PhD scholarship (APP1168925) and a Menzies Hot North funding and Stan \& Jean Perron PhD top-up scholarship. A. Schultz was supported by a NHMRC Trip fellowship (APP1168022). A.B. Chang was supported by a NHMRC Practitioner Fellowship (1058213) and has received multiple NHMRC grants related to topics of cough and bronchiectasis, including a CRE for lung disease among Indigenous children. Funding information for this article has been deposited with the Crossref Funder Registry.

\section{References}

1 Chang AB, Redding GJ, Everard ML. Chronic wet cough: protracted bronchitis, chronic suppurative lung disease and bronchiectasis. Pediatr Pulmonol 2008; 43: 519-531.

2 Chang AB, Bush A, Grimwood K. Bronchiectasis in children: diagnosis and treatment. Lancet 2018; 392: 866-879.

3 Wurzel DF, Marchant JM, Yerkovich ST, et al. Protracted bacterial bronchitis in children: natural history and risk factors for bronchiectasis. Chest 2016; 150: 1101-1108.

4 Blackall SR, Hong JB, King P, et al. Bronchiectasis in indigenous and non-indigenous residents of Australia and New Zealand. Respirology 2018; 23: 743-749.

5 Kapur N, Masters IB, Newcombe P, et al. The burden of disease in pediatric non-cystic fibrosis bronchiectasis Chest 2012; 141: 1018-1024.

6 Martinez-Garcia MA, Perpina-Tordera M, Roman-Sanchez P, et al. Quality-of-life determinants in patients with clinically stable bronchiectasis. Chest 2005; 128: 739-745.

7 McCallum GB, Chang AB. "Good enough" is "not enough" when managing indigenous adults with bronchiectasis in Australia and New Zealand. Respirology 2018; 23: 725-726.

8 Moore H, Burgner D, Carville K, et al. Diverging trends for lower respiratory infections in non-Aboriginal and Aboriginal children. J Paediatr Child Health 2007; 43: 451-457.

9 Chang AB, Masel JP, Boyce NC, et al. Non-CF bronchiectasis: clinical and HRCT evaluation. Pediatr Pulmonol 2003; 35: 477-483.

10 McCallum GB, Binks MJ. The epidemiology of chronic suppurative lung disease and bronchiectasis in children and adolescents. Front Pediatr 2017; 5: 27.

11 Chalmers JD, Chang AB, Chotirmall SH, et al. Bronchiectasis. Nat Rev Dis Primers 2018; 4: 45.

12 Usta Guc B, Asilsoy S, Durmaz C. The assessment and management of chronic cough in children according to the British Thoracic Society guidelines: descriptive, prospective, clinical trial. Clin Respir J 2014; 8: 330-337.

13 O'Grady KF, Drescher BJ, Goyal V, et al. Chronic cough postacute respiratory illness in children: a cohort study. Arch Dis Child 2017; 102: 1044-1048.

14 Marchant JM, Masters IB, Taylor SM, et al. Evaluation and outcome of young children with chronic cough. Chest 2006; 129: 1132-1141.

15 Chang AB, Robertson CF, Van Asperen PP, et al. A multicenter study on chronic cough in children: burden and etiologies based on a standardized management pathway. Chest 2012; 142: 943-950. 

2017; 50: 1602139

17 Barton J, Scott L, Maguire G. Bronchiectasis in the Kimberley region of Western Australia. Aust J Rural Health 2018; 26: 238-244.

18 The University of Adelaide. Accessibility/Remoteness Index of Australia (ARIA). https://www.adelaide.edu.au/ hugo-centre/services/aria. Date last accessed: 7 September 2019. Date last updated: 1 May 2019.

19 McKay CC, Chang AB, Versteegh LA, et al. Culturally appropriate flipcharts improve the knowledge of common respiratory conditions among Northern Territory Indigenous families. Health Promot J Austr 2015; 26 : 150-153.

20 D'Sylva P, Walker R, Lane M, et al. Chronic wet cough in Aboriginal children: it's not just a cough. J Paediatr Child Health 2019; 55: 833-843.

21 Chang $\mathrm{AB}$, Gaffney JT, Eastburn MM, et al. Cough quality in children: a comparison of subjective vs bronchoscopic findings. Respir Res 2005; 6: 3.

22 Rossman CM, Waldes R, Sampson D, et al. Effect of chest physiotherapy on the removal of mucus in patients with cystic fibrosis. Am Rev Respir Dis 1982; 126: 131-135.

23 Chang AB, Landau LI, Van Asperen PP, et al. Cough in children: definitions and clinical evaluation. Med J Aust 2006; 184: 398-403.

24 Laird P, Walker R, Lane M, et al. We won't find what we don't look for: identifying barriers and enablers of chronic wet cough in Aboriginal children. Respirology 2019; in press [https://doi.org/10.1111/resp.13642].

25 Asilsoy S, Bayram E, Agin H, et al. Evaluation of chronic cough in children. Chest 2008; 134: 1122-1128.

26 Elborn JS. Bronchiectasis. In: Gibson JG, Loddenkemper R, Sibille Y, et al., eds. The European Lung White Book. Sheffield, European Respiratory Society, 2014; pp. 176-183.

27 King PT, Holdsworth SR, Farmer M, et al. Phenotypes of adult bronchiectasis: onset of productive cough in childhood and adulthood. COPD 2009; 6: 130-136.

28 Mullan N, Codde J, Van Buynder P. Respiratory hospitalisations in Port Hedland, 1993-2004: an exploratory geographical analysis. https://www.jtsi.wa.gov.au/docs/default-source/default-document-library/ph_dust_management_ respiratory_hospitalisations_1993-2004_2006.pdf?sfvrsn=8776b1c_4. Date last accessed: 7 September 2019. Date last updated: 2006

29 Zosky GR, Boylen CE, Wong RS, et al. Variability and consistency in lung inflammatory responses to particles with a geogenic origin. Respirology 2014; 19: 58-66.

30 Watson K, Carville K, Bowman J, et al. Upper respiratory tract bacterial carriage in Aboriginal and non-Aboriginal children in a semi-arid area of Western Australia. Pediatr Infect Dis J 2006; 25: 782-790.

31 Skaar EP. The battle for iron between bacterial pathogens and their vertebrate hosts. PLoS Pathog 2010; 6 e1000949.

32 Wurzel DF, Marchant JM, Clark JE, et al. Wet cough in children: infective and inflammatory characteristics in broncho-alveolar lavage fluid. Pediatr Pulmonol 2014; 49: 561-568.

33 Chang $\mathrm{AB}$, Oppenheimer JJ, Weinberger MM, et al. Management of children with chronic wet cough and protracted bacterial bronchitis: CHEST guideline and expert panel report. Chest 2017; 151: 884-890.

34 Das S, Sockrider M. Protracted bacterial bronchitis (PBB) in children. Am J Respir Crit Care Med 2018; 198: $11-12$.

35 Australian Bureau of Statistics. National Aboriginal and Torres Strait Islander Social Survey, 2014-15. https://www. abs.gov.au/ausstats/abs@.nsf/mf/4714.0. Date last accessed: 7 September 2019. Date last updated: 21 February 2019 .

36 Stämpfli MR, Anderson G. How cigarette smoke skews immune responses to promote infection, lung disease and cancer. Nat Rev Immunol 2009; 9: 377-384.

37 Chang AB, Upham JW, Masters IB, et al. Protracted bacterial bronchitis: the last decade and the road ahead Pediatr Pulmonol 2016; 51: 225-242. 